ISSN 0206-5657. Вісник Львівського університету. Серія біологічна. 2017. Випуск 75. С. 119-126 Visnyk of the Lviv University. Series Biology. 2017. Issue 75. P. 119-126

МІКРОБІОЛОГІЯ

УДК 579.873:631.463

\title{
SCREENING OF ACTINOMYCETES - POTENTIAL BIOCONTROL AGENTS OF THE TYPICAL TREES INFECTIONS
}

\author{
S. Tistechok, V. Fedorenko, O. Gromyko
}

\author{
Ivan Franko National University of Lviv \\ 4, Hrushevskyi St., Lviv 79005, Ukraine \\ e-mail: o_gromyko@franko.lviv.ua
}

From the main ridge of Crimean mountains were isolated 564 strains of soil non-rhizospheric actinomycetes and 640 isolates from rhizosphere medicinal and endemic plants Thymus roegneri K. Koch aggr., Jurinea sordida Stev., Helianthemum stevenii Rupr. ex Juz. \& Pozd., Orchis purpurea Huds., Trinia bibershteinii Fedoronch., Potentilla depressa Willd. ex D. F. K. Schltdl. Their antimicrobial properties were studied against phytopathogenic bacteria Pseudomonas syringae IMV 8511, Xantomonas campestris pv. campestris IMV 8003, Agrobacterium tumifaciens IMV 8628 i Erwinia amylovora Mi2 and fungi Fusarium oxysporum IMV 54201, Aspergillus niger IMV 16706, which are typical infectious diseases wide range of plants, including trees. Isolates with antibacterial and antifungal properties are more represented in the rhizosphere of plants. Overall, about half non-rhizospheric or rhizospheric isolates inhibited growth of at least one test-culture. Most antagonists were found in the rhizosphere Thymus roegneri $\mathrm{K}$. Koch aggr. (67.4\%). least - in the rhizosphere Helianthemum stevenii Rupr. ex Juz. \& Pozd. (39.8 \%), there were $50.6 \%$ among non-rhizospheric strains. Most isolates inhibited growth of $X$. campestris pv. campestris (almost 30 $\%$ ), least - P. syringae (about $5 \%$ ) and fungi (not more $3 \%$ ). We isolated 18 strains, which are capable of inhibiting all used phytopathogenic bacteria (10 non-rhizospheric and 8 with rhizosphere of plants), 35 isolates inhibited growth Fusarium oxysporum and Fusarium oxysporum, of which 27 were non-rhizospheric. Also we isolated 4 strains of non-rhizospheric actinomycetes which showed activity against all used test-cultures. At the same time in non-rhizosphere soil more isolates were found that supressed the growth of pathogenic bacteria or fungi, and 4 actinomycete strains have antimicrobial activity against all teststrains. We selected 57 isolates for further research that could be potential biocontrol agents of infectious diseases of trees.

Keywords: Actinomycetes, diseases of trees, biocontrol

Trees and woody crops occupy about $40 \%$ of the world's land surface and are extremely important for life on Earth [4]. Except forests, large areas of agricultural land covered nurseries of fruit and ornamental trees. Also significant share is occupied by plantation parks in urban ecosystems. Wood plantations play a major role in nutrient cycling, prevent soil erosion, mitigate the effects of climate change [21]. Particularly important role trees play in the big cities as a powerful factor in combating natural and man-made urban pollution. However urbo technological environments negatively affect the living condition of plants and reduces their resistance to infectious diseases [10].

The largest part of viruses, bacteria, fungi, nematodes cause a wide range of diseases of plants, including trees, reducing their life expectancy, phytoameliorative role and decorative appeal [3]. The most common phytopathogenic bacteria are genera Pseudomonas, Xanthomonas, Pectobacterium, Agrobacterium, Erwinia etc. They can cause frostbite, leaf spot, necrosis, rot,

(C) Тістечок С., Федоренко В., Громико О., 2017 
burns, tumors at the crown galls of the trees, and the plants root system, and often the cause epiphytoties $[6,8,14,27]$. There are a variety soil pathogens such fungi (for example, Fusarium, Armillaria, Botrytis, Aspergillus, Verticillium etc.), which also cause a wide range of diseases of trees [3]. During the last decade, frequency of new emergent plant diseases, caused by microorganisms, is increased that are characterized by severe symptoms, control of which is challenging [22]. Given this search for new antimicrobial agents and the development of modern methods of biocontrol does't lose its relevance.

Inexhaustible natural source of bioactive compounds (enzymes, antibiotics, etc.), can inhibit the development of pathogens are microorganisms, including actinomycetes. About $75 \%$ of known antibiotics produced by actinomycetes [4]. This soil microorganisms able to form a welldeveloped mycelium that colonized the root system of plants [2]. They play an important role in functioning of rhizosphere microbiota as antagonists of pathogens, producers of phytohormones of which are molecules able to transform insoluble mineral nutrients of plants. Today, there are many reports about use actinomycetes as biocontrol agents of infections diseases of crops as an alternative to agrochemicals $[7,12,13]$. However, there are very few reports, which presents data on the use of actinomycetes to protect the trees, especially in urban ecosystems [26].

The soil in the world - one of the major habitats actinomycetes. Composition of soils, climate, vegetation diversity have floated to their considerable diversity. From this perspective Crimean peninsula is a very interesting piece of the earth's land with a variety of continental climate in the north to subtropical in the southern Black Sea coast, a wide range of different types of soils and unique vegetation. The diversity and biological properties actinomycetes Crimean peninsula is poorly studied [1]. In previous studies we have described antagonistic properties actinomycetes of rhizosphere some plants, Nikita Botanical Gardens, located on the Crimean Peninsula, including strains revealed a number of broad antimicrobial properties [11], and producers of new antibiotics [18-20].

The aim of this work was screening of actinomycetes soil and rhizosphere of rare and endemic plants of the Crimean peninsula, that are capable of inhibiting pathogens a wide range of plants, and trees.

\section{Materials and methods}

Sampling of soil. Samples of non-rhizosphere soil were taken in 2013 in six different parts of Ai-Petri $\left(44^{\circ} 27^{\prime} 4^{\prime \prime} \mathrm{N}, 34^{\circ} 3^{\prime} 10^{\prime \prime}\right)$ in depth 3-5 sm (Fig. 1). Put them in a sterile paper bags. Collecting the rhizosphere samples was carried out on the slopes of the spine Nikita $\left(44^{\circ} 33^{\prime} 40^{\prime \prime}\right.$, $34^{\circ} 12^{\prime} 30^{\prime \prime}$ ) following way. Around the plants dug a small trench, once selected soil around the root system, sterile scissors cut the required number of roots, put them in a sterile paper bags. Samples of soil and plant roots stored at $4{ }^{\circ} \mathrm{C}$.

Isolation of actinomycetes. Isolation of actinomycetes from soil samples was carried out in three ways: (I) $1 \mathrm{~g}$ soil sample was placed in a test-tube with $10 \mathrm{ml}$ of sterile water and stirred for 15 minutes rocking; (II) $1 \mathrm{~g}$ soil sample was placed in a test-tube with $10 \mathrm{ml}$ of $1.5 \%$ aqueous phenol and stirred for 30 minutes rocking; (III) $1 \mathrm{~g}$ sample of soil roasted for 60 minutes at 100 ${ }^{\circ} \mathrm{C}$, on the same (I). Isolation of actinomycetes with rhizosphere sample performed similarly, but used a sample of 2-3 $\mathrm{g}$ of roots that are washed in a flask with $100 \mathrm{ml}$ of sterile water or a solution of phenol.

The resulting suspension in a volume of $1 \mathrm{ml}$ was transferred into a sterile microtubes, made a 10 -fold dilution and plated breeding $\left(10^{-2}-10^{-4}\right)$ in a petri dish of the mediums: ISP3, ISP4 [23], medium with sodium propionate [28], medium with chitin [28], Gause 2 [9], HVA [29]. For inhibiting growth of other bacteria and fungi in the medium added nalidixic acid (25 $\mu \mathrm{g} / \mathrm{ml})$ and nystatin $(50 \mu \mathrm{g} / \mathrm{ml})$ [15]. Incubated for 24 days at $28^{\circ} \mathrm{C}$. Colonies were selected for 
the characteristic actinomycetes growth and morphology. Selected culture isolates were stored in TSB with the addition of an equal volume of $50 \%$ glycerol solution at $-20{ }^{\circ} \mathrm{C}$. Isolated strains of actinomycetes are deposited in the Culture Collection of Microorganisms - producers of antibiotics of Ivan Franko National University of Lviv.

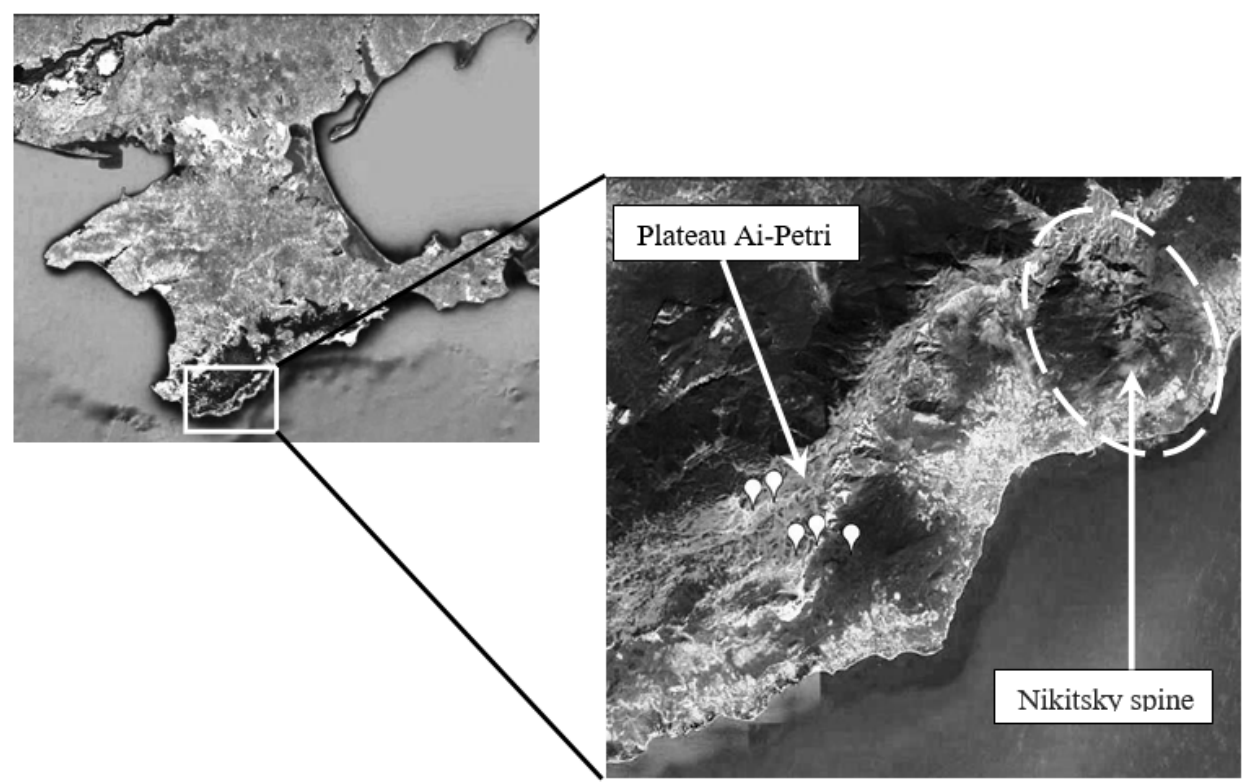

Fig. 1. Soil sampling points on the Crimean peninsula

Test-organism. For the study of antagonistic properties such test-cultures were used strains phytopathogens bacteria Pseudomonas syringae IMV 8511, Xantomonas campestris pv. campestris IMV 8003, Agrobacterium tumifaciens IMV 8628, Erwinia amylovora Mi2 and fungi Fusarium oxysporum IMV 54201, Aspergillus niger IMV 16706. Bacteria was grown in LA [15], fungi was grown in the Saburo-medium [15].

Screening antagonistic activity. Antagonistic properties of selected strains of actinomycetes against of bacteria were investigated by following way: on 6 isolates stab plated on Petri dishes with OM (oatmeal $-40 \mathrm{~g}$, agar $-18 \mathrm{~g}$, tap water $-1000 \mathrm{ml}$, pH 7.5). After 7 days growth of colonies formed, filled $0.7 \%$ LA [3], which contained $10^{9}$ cells $/ \mathrm{ml}$ test-cultures. The results were evaluated by 2 days of growth for the formation of zones inhibition growth of testcultures.

The ability to inhibit the growth of fungi studied using of double culture method. Isolates were seeded in the same way as has been described. After 3 days of growth strains actinomycetes centered agar plates seeded stab culture of the fungus. Results (growth inhibition test-cultures) evaluated after 3-4 days of growth.

Statistical analysis. Statistical analysis of the results was performed using Microsoft Excel.

\section{Results and discussion}

Using three different approaches generally were isolated 1204 actinomycete-like isolates (Table 1). Of the six samples non-rhizosphere soil at Ai-Petri at an altitude of 1209 m.a.s.l. collectively isolated 564 isolates $(376$ - by direct seeding soil suspensions, 21 - after handling soil suspensions $1.5 \%$ solution of phenol and 167 - after roasted). The remaining 647 isolates 
isolated from the rhizosphere samples of medicine, rare and endemic plants Crimean peninsula, collected on the slopes Nikitskaya plateau at an altitude of 250 to 1200 m.a.s.l. Particularly from rhizosphere Thymus roegneri K. Koch aggr. were isolated 91 isolates, Orchis purpurea Huds. 60, Jurinea sordida Stev. - 149, Helianthemum stevenii Rupr. ex Juz. \& Pozd. - 108, Trinia bibershteinii Fedoronch. - 140, Potentilla depressa Willd. ex D. F. K. Schltdl. - 92 isolates.

Table 1

Distribution of actinomycetes in different soil samples

\begin{tabular}{|c|c|c|c|c|}
\hline & $\mathrm{I}^{*}$ & II & III & Total (\%) \\
\hline Non-rhizospheric & 376 & 21 & 167 & $564(46.8)$ \\
\hline \multicolumn{5}{|l|}{ Rhizospheric: } \\
\hline Thymus roegneri $\mathrm{K}$. Koch aggr. & 88 & 1 & 2 & 91 (7.6) \\
\hline Jurinea sordida Stev. & 146 & 0 & 3 & $149(12.4)$ \\
\hline Helianthemum stevenii Rupr. ex Juz. \& Pozd. & 100 & 8 & 0 & $108(9.0)$ \\
\hline Orchis purpurea Huds. & 34 & 26 & 0 & $60(5.0)$ \\
\hline Trinia bibershteinii Fedoronch. & 135 & 5 & 0 & 140 (11.6) \\
\hline Potentilla depressa Willd. ex D. F. K. Schltdl. & 56 & 36 & 0 & $92(7.6)$ \\
\hline
\end{tabular}

Note: The processing techniques described in «Materials and methods»

After investigation of antagonistic properties of selected isolates revealed that about $50 \%$ isolates of non-rhizospheric and rhizospheric found to inhibit at least one of the used test-cultures. Most strains are delayed growth of at least one test-culture isolated from the rhizosphere T. roegneri $(67.4 \%)$. Somewhat less active cultures found in the rhizosphere $J$. sordida $(54.4 \%), O$. purpurea i P. depressa (to $53.3 \%$ ) and least - T. bibershteinii (49.3\%) and H. stevenii (39.8 \%). Antagonistic properties among non-rhizospheric isolates revealed $50.6 \%$ of strains.

Among non-rhizospheric isolates that have antibacterial properties against gram-negative phytopathogens, detained about a third growth $X$. campestris $p v$. campestris and $28.8 \%$ E. amylovora. Considerably less was antagonists A. tumifaciens and $P$. syringae $(7.3$ and $5.1 \%$, respectively) (Fig. 2). The rhizospheric isolates also often suppressed growth $X$. campestris $p v$. campestris (24\% in the aggregate). Most of antagonists with pathogens inhibition properties were found in the rhizosphere P. depressa (39.1\%), T. roegneri $(28.6 \%)$ and J. sordida (26.8\%). About $16 \%$ of all rhizosphere isolates suppresed growth of E. amylovora, the largest share of which was allocated from $T$. roegneri $(33.7 \%)$ and P. depressa $(26.1 \%)$ rhizosphere. Much less isolates of rhizospheric actinomycetes inhibited growth of A. tumifaciens (5.2\%); the largest proportion of strains were found in T. roegneri $(11.2 \%)$ and $O$. purpurea $(10.0 \%)$ rhizosphere, and the smallest - in $J$. sordida $(0.7 \%)$ rhizosphere. Only $2.3 \%$ of rhizospheric actinomycete strains were capable of $P$. syringae growth suppression. In particular, there were about $5 \%$ of them in $P$. depressa, T. roegneri and H. stevenii rhizosphere. In other plants rhizosphere antagonists of phytopathogenic was no more $1 \%$.

In addition, $10.3 \%$ isolates were found among non-rhizospheric actinomycete strains. This isolates are capable of $A$. niger and less F. oxysporum (6.4 \%) growth supression (Fig. 3 ). The largest number of isolates with fungicidal activity among rhizospheric actinomycete strains were isolated from the rhizosphere of J. sordida (6.7 \% to F. oxysporum and $10.7 \%$ to A. niger). In the rhizosphere $T$. roegneri, $P$. depressa and $T$. bibershteinii antagonists of these fungi was not more than $2.2 \%$. There was no similar strains in rhizosphere of other studied plants.

We found 18 isolates capable to suppress all used phytopathogenic bacteria (10 non-rhizospheric and 8 in the rhizosphere of plans) among the studied strains (Table 2). There were 35 strains that would inhibit growth of $F$. oxysporum and A. niger; most of them ( 27 isolates) were isolated from non-rhizospheric soil samples. We selected 4 actinomycete strains, which have antimicrobial activity against all test-strains. 


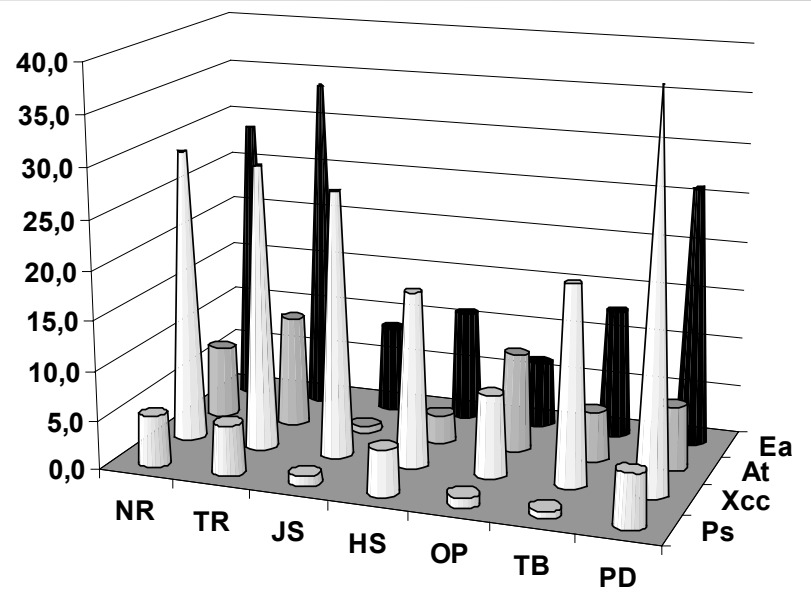

Fig. 2. Percentage of active actinomycete isolates antagonising different test-bacteria. Ps - P. syringae, $\mathrm{Xcc}-X$. campestris pv. campestris, At - A. tumifaciens, Ea - E. amylovora, NR - Non-rhizospheric actinomycetes, TR $-T$. roegneri, JS - J. sordida, HS - H. stevenii, OP - O. purpurea, TB $-T$. bibershteinii, $\mathrm{PD}-P$. depressa

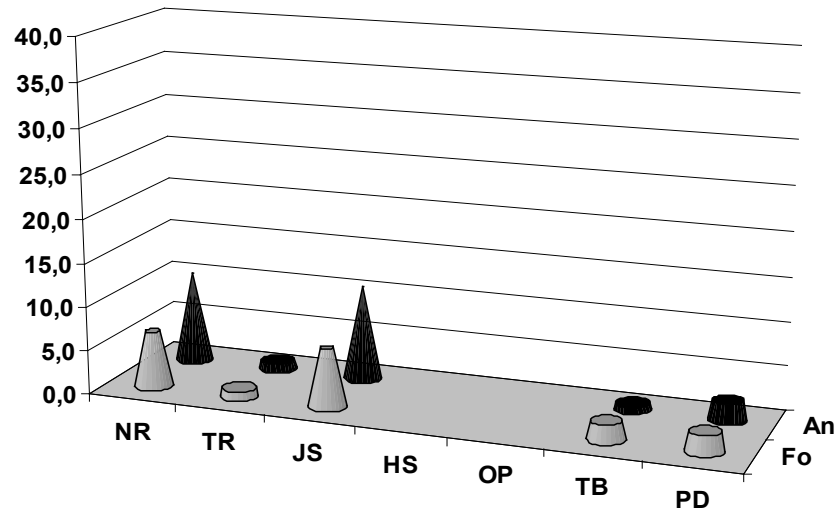

Fig. 3. Percentage of active actinomycete isolates antagonising different test-cultures. Fo $-F$. oxysporum, An $-A$. niger. The rest of the cuts as in Fig. 2

Table 2

Actinomycetes number of strains with a wide range of antagonistic activity

\begin{tabular}{|c|c|c|c|}
\hline Soil sample & Bacteria & Fungi & Bacteria+Fungi \\
\hline Non-rhizospheric & 10 & 27 & 4 \\
\hline \multicolumn{4}{|l|}{ Rhizospheric: } \\
\hline Thymus roegneri $\mathrm{K}$. Koch aggr. & 1 & 0 & 0 \\
\hline Jurinea sordida Stev. & 3 & 1 & 0 \\
\hline Helianthemum stevenii Rupr. ex Juz. \& Pozd. & 1 & 4 & 0 \\
\hline Orchis purpurea Huds. & 1 & 0 & 0 \\
\hline Trinia bibershteinii Fedoronch. & 0 & 1 & 0 \\
\hline Potentilla depressa Willd. ex D. F. K. Schltdl. & 2 & 2 & 0 \\
\hline Total & 18 & 35 & 4 \\
\hline
\end{tabular}

These data shows that strains with antibacterial and antifungal properties are more represented in the rhizosphere of plants, than in non-rhizospheric soil. Apparently it is caused by increased concentration of nutrients in the root zone, especially in the area of root growth. So ac- 
tinomycetes, competing for easily accessible power supply with other groups of microorganisms, resorting to the synthesis of biologically active molecules, including antibiotics to inhibit the development of competition. However, we found significantly more isolates that supressed the growth of pathogenic bacteria, or fungi, or all used test-cultures in non-rhizosphere soil. Obviously, plants often affect the microbial communities in the rhizosphere as synthetics of a whole range of biologically active molecules, suppressing the growth of undesirable microorganisms than creating a certain extent an additional barrier to the active development of pathogens [25]. Soil, which was taken from the plants root system is aggressive habitats with increased levels of competition for power. So non-rhizospheric actinobacteria obviously have to synthesize a wider range of molecules with antimicrobial properties to fight for survival. The results of this study show, that about half isolated actinomycete strains from soil and rhizosphere of plants on the Crimean peninsula have potential as agents of biological control of many pathogenic bacteria and fungi, that can cause a wide range of plant diseases, including trees. However, most of them were found to inhibit no more than 1-2 pathogen strains. Similar results were obtained by researchers who isolated similar actinomycete strains from other natural biotops [16, 17, 24]. Meanwhile, some described isolates in this paper have a wide range of antagonistic properties, growth inhibiting of test-cultures used in this work.

Thus, we have selected 57 actinomycete strains that demonstrated the ability to inhibit the growth of a wide range of pathogenic microorganisms. The selected isolates may be potential biocontrol agents of infectious diseases of trees

We express our sincere gratitude Tree Research \& Education Endowment Fund (TREE Fund) for the financial support of the research grant within №14-JK-01.

\section{REFERENCES}

1. Andrejuk E. I., Vladymyrova E. V., Kohan S. B. Actinomycetes of the soils of the south of the European part of the USSR and their biological activit. K.: Naukova Dumka, 1974. 143 p. (In Russian).

2. Buée M., De Boer W., Martin F. et al. The rhizosphere zoo: An overview of plant-associated communities of microorganisms, including phages, bacteria, archaea, and fungi, and of some of their structuring factors // Plant Soil. 2009. Vol. 321. P. 189-212.

3. Cazorla F. M., Mercado-Blanco J. Biological control of tree and woody plant diseases: an impossible task? // BioControl. 2016. Vol. 61. P. 233-242.

4. Chaudhary H. S., Soni B., Shrivastava A. R. et al. Diversity and versatility of actinomycetes and its role in antibiotic production // J. Appl. Pharm. Science. 2013. Vol. 3 (8 Suppl 1). P. S83-S94.

5. Crowther T.W, Glick H. B, Covey K. R. et al. Mapping tree density at a global scale // Nature. 2015. Vol. 525. P. 201-205.

6. de Cleene M, de Ley J. The host range of Crown gall // Bot Rev. 1976. Vol. 42. P. 388-466.

7. Faheem M., Raza W., Zhong $W$. et al Evaluation of the biocontrol potential of Streptomyces goshikiensis YCXU against Fusarium oxysporum f. sp. Niveum // BioControl. 2015. Vol. 81. P. 101-110.

8. Fire Blight: The Disease and its Causative Agent, Erwinia amylovora. // Edited by J.L. Vanneste / Wallingford, UK: CABI, 2000. 370 p.

9. Gauze G. F., Preobrazhenskaya T. P., Sveshnikova M. A. et al. The determinant of actinomycetes. M: Science, 1983. 245 p. (In Russian).

10. Gnativ P. S. Functional diagnostic of dendroecology: Scientific monograph. Lviv: Prospect "Kamula", 2014. 336 p. (In Ukrainian). 
11. Gromyko O. Antagonistic properties of actinomycetes from the ryzosphere of Olea europaea L. // Visnyk of Lviv Univ. Biology Series. 2012. Is. 59. P. 209-215. (In Ukrainian).

12. Janaki T., Nayak B.K., Ganesan T. Antifungal activity of soil actinomycetes from the mangrove Avicennia marina // J. Med. Plants Studies. 2016. Vol. 4(2). P. 5-8.

13. Kaur T., Sharma D., Kaur A., Manhas R. Antagonistic and plant growth promoting activities of endophytic and soil actinomycetes // Arch. Phyt. Plant Prot. 2013. Vol. 46. Iss.14. P. $1756-1768$.

14. Kennelly M. M., Cazorla F.M., de Vicente A. et al. Pseudomonas syringae diseases of fruit trees - progress toward understanding and control // Plant Dis. 2007. Vol. 91. P. 4-17.

15. Kieser T., Bibb M., Buttner M. et al. Practical Streptromyces genetics. Norwich: John Innes Foundation, 2000. $634 \mathrm{p}$.

16. Ningthoujam D. S., Sanasam S., Nimaichand S. Screening of Actinomycete isolates from niche habitats in Manipur for antibiotic activity // Am. J. Biochem. Biotech. 2009. Vol. 5. N 4. P. 221-225.

17. Nurkanto A, Julistiono H., Agusta A., Sjamsuridza W. Screening antimicrobial activity of actinomycetes isolated from Raja Ampat, West Papua, Indonesia Makara // J. Sci. 2012. Vol. 16/1. P. 21-26.

18. Raju R., Gromyko O., Fedorenko V. et al. Rubimycinone A, a new anthraquinone from a terrestrial Streptomyces $s p$. // Tetrahedron Lett. 2013. Vol. 54. Is. 8. P. 900-902.

19. Raju R., Gromyko O., Fedorenko $V$. et al. Oleaceran: A novel npiro[isobenzofuran-1,2'-naptho[1,8-bc]furan] isolated from a terrestrial Streptomyces sp. Organic Lett. 2013. Vol. 15. Is.14. P. 3487-3489.

20. Raju R., Gromyko O., Butsiak A. et al. Oleamycins A and B: new antibacterial cyclic hexadepsipeptides isolated from a terrestrial Streptomyces sp. // J. Antibiot. 2014. Vol. 67. P. 339-343.

21. Ruano-Rosa D, Mercado-Blanco J. Combining biocontrol agents and organics amendments to manage soil-borne phytopathogens. In: Meghvansi MK, Varma A (eds) Organic amendments and soil suppressiveness in plant disease management, soil biology // Springer Int. Pub. 2015. Vol. 46. P. 457-478.

22. Santini A., Ghelardini L., De Pace C. et al. Biogeographical patterns and determinants of invasion by forest pathogens in Europe // New Phytol. 2013. Vol. 197. P. 238-250.

23. Shirling E.B., Gottlieb D. Methods for characterization of Streptomyces species // Int. J. Syst. Bacteriol. 1966. Vol. 16. N 3. P. 313-340.

24. Taechowisan T., Peberdy J. F., Lumyoung S. Isolation of endophytic Actinomycetes from selected plants and their antifungal activity // World J. Microbiol. Biotechnol. 2003. Vol. 19. P. 381-385.

25. The handbook of microbial bioresources / Edited by V. Gupta, G. Sharma, M. Tuohy, R. Gaur. Boston: CABI, 2016. 700 p.

26. Vasconcellos R., Cardoso E. Rhizospheric streptomycetes as potential biocontrol agents of Fusarium and Armillaria pine rot and as PGPR for Pinus taeda // BioControl. 2009. Vol. 54. P. 807-816.

27. Williams P. H. Black rot: a continuing threat to world crucifers // Plant Dis. 1980. Vol. 64. P. 736-742.

28. Zenova G. M. Soil actinomycetes: Tutorial. M: MSU. 1992. 79 p. (In Russian).

29. Zhang J. Improvement of an Isolation Medium for Actinomycetes // Modern App. Sci. 2011. Vol. 5. N 2. P. 124-127. 


\title{
СКРИНІНГ АКТИНОМЦЕТІВ - ПОТЕНЦІЙНИХ АГЕНТІВ БІОКОНТРОЛЮ ТИПОВИХ ЗБУДНИКІВ ІНФЕКЦІЙНИХ ЗАХВОРЮВАНЬ ДЕРЕВ
}

\section{С. Тістечок, В. Федоренко, О. Громико}

\author{
Львівський національний університет імені Івана Франка \\ вул. Грушевського, 4, Львів 79005, Україна \\ e-mail: o_gromyko@franko.lviv.ua
}

На території головної гряди Кримський гір виділили 564 штами грунтових позаризосферних актиноміцетів і 640 ізолятів із ризосфери лікарських та ендемічних рослин Thymus roegneri K. Koch aggr., Jurinea sordida Stev., Helianthemum stevenii Rupr. ex Juz. \& Pozd., Orchis purpurea Huds., Trinia bibershteinii Fedoronch., Potentilla depressa Willd. ex D. F. K. Schltdl. Досліджено їхні антимікробні властивості проти фітопатогенних бактерій Pseudomonas syringae IMB 8511, Xantomonas campestris pv. campestris IMB 8003, Agrobacterium tumifaciens IMB 8628 i Erwinia amylovora Mi2 та грибів Fusarium oxysporum IMB 54201, Aspergillus niger IMB 16706 - типових збудників інфекційних захворювань широкого кола рослин, у т.ч. деревних порід. Ізоляти 3 антибактерійними й антифунгальними властивостями більшою мірою представлені в ризосфері рослин. Загалом близько половини позаризосферних чи ризосферних ізолятів пригнічували ріст хоча б однієї тест-культури. Найбільше антагоністів виявили в ризосфері Thymus roegneri K. Koch aggr. (67,4 \%), найменше - в ризосфері Helianthemum stevenii Rupr. ex Juz. \& Pozd. (39,8 \%), серед позаризосферних штамів таких було 50,6 \%. Найбільша кількість ізолятів затримувала ріст $X$. campestris pv. campestris (майже $30 \%$ ), найменша - P. syringae (близько $5 \%$ ) і грибів (не більше $3 \%$ ). Виділено 18 ізолятів, здатних пригнічувати всі використані фітопатогенні бактерії (10 позаризосферних і 8 із ризосфери рослин), 35 ізолятів пригнічували ріст і $F$. oxysporum, i A. ni$g e r$, із яких 27 - позаризосферні. Також виділено 4 штами позаризосферних актиноміцетів, які виявляли активність проти всіх використаних тест-культур.

Ключові слова: Actinomycetes, захворювання дерев, біоконтроль 